\title{
KAJIAN PENYEBAB JALAN AMBLES PADA RUAS JALAN BANJARPARAKAN-MENGANTI KABUPATEN BANYUMAS
}

\author{
${ }^{1)}$ Amris Azizi, ${ }^{2)}$ M. Agus Salim \\ ${ }^{1,2)}$ Program Studi Teknik Sipil, Fakultas Teknik dan Sains \\ Universitas Muhammadiyah Purwokerto \\ Jl. Raya Dukuh Waluh PO Box 202 Purwokerto \\ Email : amris.azizi@gmail.com, assalimaku@gmail.com
}

\section{Informasi Makalah}

Dikirim, 20 September 2019

Direvisi, 06 April 2010

Diterima, 15 April 2020

\section{Kata Kunci:}

ambles

longsor

ruas jalan Banjarparakan-

Menganti

\begin{abstract}
INTISARI
Ruas jalan Banjarparakan-Menganti Kabupaten Banyumas berulang kali mengalami ambles dan longsor lereng pada titik yang sama. Ambles dan longsor menimbulkan masalah transportasi karena ruas jalan ini merupakan jalan utama di Desa Banjarparakan Kecamatan Rawalo. Ambles dan longsor meliputi hampir seluruh lebar badan jalan dengan panjang longsoran lebih kurang 50 meter. Penanganan yang dilakukan selama ini belum menghasilkan solusi yang baik, karena longsor dan ambles masih terjadi.

Tujuan penelitian adalah mengkaji karakteristik tanah dasar jalan dan stabilitas lereng ruas jalan Banjarparakan-Menganti. Kajian dilakukan untuk menemukan jawaban penyebab terjadinya longsor lereng dan ambles di ruas jalan Banjarparakan-Menganti. Karakteristik tanah dasar dianalisis dengan pendekatan parameter batas-batas Atterberg, dan stabilitas lereng dianalisis dengan software Geostudio Slope/W

Hasil analisis menunjukkan tanah dasar dibawah timbunan ruas jalan Banjarparakan-Menganti berupa endapan fluvial yang sangat mudah sekali longsor bila tidak dalam kondisi tertahan. Tanah dasar (subbase) ruas jalan Banjarparakan-Menganti mempunyai nilai $\mathrm{PI}=11,4 \%$, termasuk tanah lempung berlanau, kohesif dan mempunyai sifat plastisitas sedang. Tanah jenis ini mempunyai karakteristik tanah yang kurang baik, karena sering menimbulkan penurunan yang berlebihan, gerakan dinding penahan tanah, keruntuhan lereng, dan lain-lain. Stabilitas lereng ruas jalan BanjarparakanMenganti eksisting pada tiga stasiun pengamatan termasuk kategori stabil. Penyebab longsor lereng dan amblesnya ruas jalan Banjarparakan-Menganti diperkirakan karena pemancangan tiang pancang tidak mencapai tanah keras, tambahan beban dinding penahan tanah pada lereng, dan pengaruh tekanan air pori yang diperkirakan cukup besar, terutama bila terjadi hujan.
\end{abstract}

\section{ABSTRACT}

The Banjarparakan-Menganti road section in Banyumas district has subsidence and landslides slope at the same point. Subsidence and landslides cause transportation problems because this road is the main road in Banjarparakan village, Rawalo subdistrict. Subsidence and landslides the width of the road body with an avalanche of approximately 50 meters. Handling carried out so far has not produced a good solution, because landslides and subsidence still occur.

The aim of the study was to examine the characteristics of the subgrade and the vulnerability of the Banjarparakan-Menganti slope. The study was conducted to get answers to questions about slope landslides and subsidence on the Banjarparakan-Menganti road section. Soil characteristics analyzed with Atterberg boundary parameters, and lower bound were analyzed by Geostudio Slope / W software

The results of the analysis show that the subgrade under the BanjarparakanMenganti road embankment is a fluvial deposit which is very easily landslide 
\begin{tabular}{l|l|l}
\hline \hline \multirow{2}{*}{$\begin{array}{l}\text { if it is not in a restrained condition. The sub-base of the Banjarparakan- } \\
\text { Menganti road has a PI value of 11.4\%, including silty clay, cohesive and has } \\
\text { moderate plasticity. This type of land has poor soil characteristics, because of } \\
\text { frequent reductions, retaining wall movements, slope failure, and so on. The } \\
\text { stability of the Banjarparakan-Menganti road slope is in three election } \\
\text { stations including the stable category. The causes of slope landslides and } \\
\text { ambles in the Banjarparakan-Menganti road are estimated because the design } \\
\text { of the pile does not reach hard ground, additional retaining walls on the } \\
\text { slopes, and the required water pressure is quite large, according to the needs } \\
\text { of the rain. }\end{array}$}
\end{tabular}

\section{Korespondensi Penulis:}

\section{Amris Azizi}

Program Studi Teknik Sipil, Fakultas Teknik dan Sains

Universitas Muhammadiyah Purwokerto

J1. Raya Dukuh Waluh PO Box 202 Purwokerto

Email : amris.azizi@gmail.com, assalimaku@gmail.com

\section{PENDAHULUAN}

Ruas jalan Banjarparakan-Menganti mempunyai panjang 1,9 km dengan lebar 4-7 m. Ruas jalan yang tepatnya di Grumbul Banjarwaru, ini termasuk jalan Kabupaten yang membentang dari utara ke selatan. Disebelah barat jalan terdapat perumahan warga, dan disebelah timur terdapat sungai Sungkalan.

Ruas jalan ini telah mengalami tiga kali longsor dan ambles, yaitu pada tahun 2014, awal Desember tahun 2016, dan awal tahun 2018. Peristiwa jalan ambles pada tahun 2014 terjadi di sta 0+175 sampai 0+225. Kejadian yang sama dan terjadi pada lokasi yang sama tahun 2016 menimbulkan retak (cracking) hingga akhirnya jalan tersebut ambles (depression) (Suryanto, 2017). Setelah ambles pada 2016, ruas jalan mengalami perbaikan dengan memasang pondasi tiang. Namun pada awal tahun 2018 longsor dan ambles kembali terjadi di titik yang sama. Amblesan terjadi sepanjang 50 meter dengan kedalaman 3-5 meter, kondisi ini mengakibatkan terputusnya jalan sebagai akses utama aktivitas warga

Tujuan penelitian adalah mengkaji karakteristik tanah dasar jalan dan stabilitas lereng ruas jalan Banjarparakan-Menganti. Analisis dilakukan untuk menemukan jawaban penyebab terjadinya longsor lereng dan ambles di ruas jalan Banjarparakan-Menganti. Kondisi tanah bawah permukaan jalan dan stabilitas lereng menjadi hal penting untuk dikaji guna mengetahui penyebab jalan longsor dan ambles.

\section{METODE}

Lokasi penelitian adalah ruas jalan Banjarparakan-Menganti, Kecamatan Rawalo, Kabupaten Banyumas. 


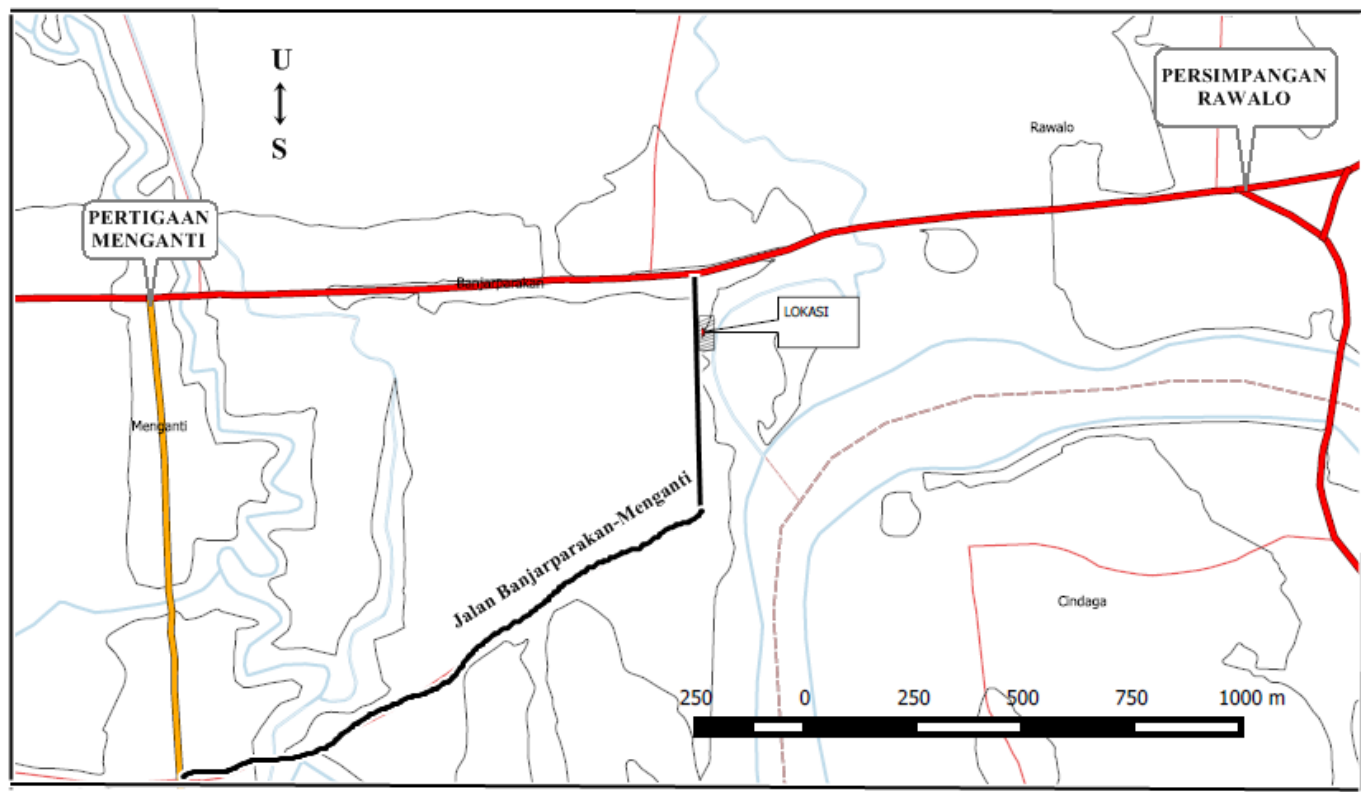

Sumber : Dinas PU Kab. Banyumas, 2016

Gambar 1 Peta Lokasi Penelitian

Data hasil uji sampel tanah berupa data sekunder dari Dinas PU Kabupaten Banyumas. Analisis hasil uji sampel tanah dilakukan untuk menentukan jenis dan karakteristik tanah pada lereng dan tanah dasar (subgrade) jalan. Jenis dan karakteristik tanah dasar ditentukan oleh parameter batas-batas konsistensi Atterberg (batas cair, batas plastis, batas susut, Indeks Plastisitas).

Analisis kestabilan lereng jalan untuk mendapatkan angka aman (FS) dilakukan dengan perhitungan berdasarkan data-data yang diperoleh dan telah dideskripsikan (perian) secara terinci dari lapangan dan data sekunder. Metode analisis stabilitas lereng yang dipakai dalam penelitian ini adalah metode yang dikembangkan oleh Fellenius. Metode ini menganggap gaya-gaya yang bekerja pada sisi kanan-kiri dari sembarang irisan mempunyai resultan nol pada arah tegak lurus bidang longsor. Analisis menggunakan Program Geostudio/Slope W

\section{HASIL DAN PEMBAHASAN}

Ruas Jalan Banjarparakan-Menganti Kabupaten Banyumas merupakan ruas jalan kabupaten dengan kelas jalan IIIB. Jalan Banjarparakan-Menganti mempunyai panjang 1,9 km dengan lebar perkerasan 5-6 m, terdiri dari dua arah dan dua lajur serta dengan bahu jalan selebar $1 \mathrm{~m}$ pada arah samping kanan dan kiri jalan.

Kerusakan Jalan pada ruas Jalan Banjarparakan-Menganti pertama kali terjadi pada tahun 2014 dan kerusakan yang kedua terjadi pada awal bulan Desember tahun 2016. Jalan yang mengalami longsor dan ambles sepanjang $\pm 50 \mathrm{~m}$ dengan kedalaman amblesan $\pm 5 \mathrm{~m}$ dan lebar $\pm 7 \mathrm{~m}$.

Gerakan tanah pada lereng menimbulkan longsor lereng sepanjang $\pm 50 \mathrm{~m}$ dan menimbulkan kerusakan dinding penahan tanah yang terbuat dari kombinasi susunan batu kali dan beton. 
Data yang diperoleh dari Dinas Pekerjaan Umum Kabupaten Banyumas (2017), menunjukkan perkuatan pada tanah dasar lereng di desain menggunakan pondasi tiang pancang dengan kedalaman 12 meter dari dasar dinding penahan tanah. Kondisi tiang pancang di lapangan tidak dapat diamati karena berada di bawah permukaan tanah dasar dinding penahan tanah.

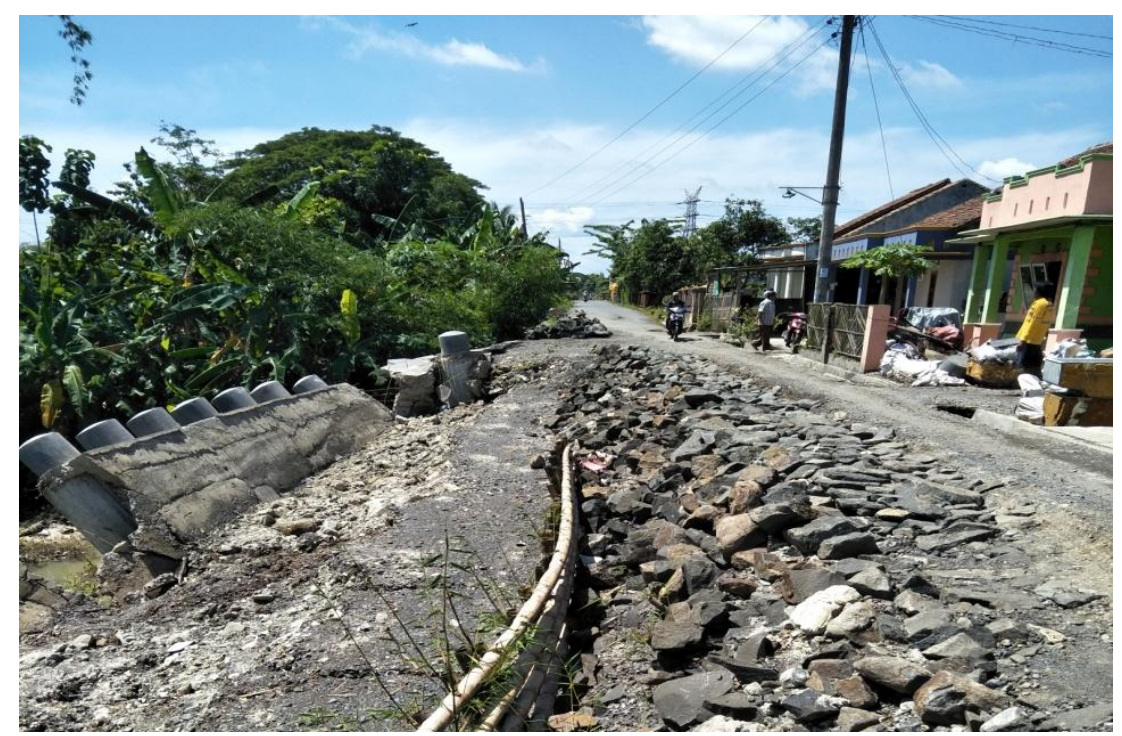

Gambar 2 Kondisi Kerusakan Ruas Jalan Banjarparakan-Menganti Kabupaten Banyumas (Sumber: pengamatan dilapangan, 2018)

\section{Parameter Karakteristik Tanah Dasar Ruas Jalan Banjarparakan-Menganti}

Tanah dasar (subbase) ruas jalan Banjarparakan-Menganti Kabupaten Banyumas merupakan tanah timbunan. Uji parameter karakteristik tanah dilakukan pada sampel tanah dasar jalan sampai kedalaman 1 meter (Dinas SDABM Kab.Banyumas,2016).

Jenis tanah pada lereng jalan yang mengalami longsor dan ambles sampai kaki lereng mempunyai kedalaman \pm 4 meter menunjukkan ciri fisik yang sama. Dengan menganggap tanah pada Stasiun pengamatan 1, 2, dan 3 sama, maka parameter tanah yang di dapat ditunjukkan pada Tabel 1.

Tabel 1 Hasil Uji Tanah Dasar

Ruas Jalan Banjarparakan-Menganti

\begin{tabular}{cccc}
\hline No. & Parameter Tanah & Satuan & Hasil Uji \\
\hline 1 & Berat isi $(\gamma)$ & Gr/cc & 1,10 \\
2 & Kadar Lempung & $\%$ & 8,00 \\
3 & Batas Cair (LL) & $\%$ & 69,5 \\
4 & Batas Plastis (PL) & $\%$ & 58,1 \\
5 & Indeks Plastisitas (PI) & $\%$ & 11,4 \\
6 & Kadar Air (w) & $\%$ & 1,82 \\
7 & CBR & $\%$ & 5,6 \\
\hline
\end{tabular}

Sumber : diolah dari Dinas PU Kab. Banyumas, 2017

\section{Kondisi Topografi dan Kondisi Vegetasi}

Sisi barat ruas Jalan Banjarparakan-Menganti merupakan kawasan pemukiman di sebelah timur berbatasan dengan Sungai Sungkalan yang bermuara ke Sungai Serayu. Ruas jalan relatif datar dengan kemiringan lereng sisi timur seperti pada Tabel 2. 
Tabel 2 Tabel Kemiringan Lereng

\begin{tabular}{ccc}
\hline No & Sta & Sudut kemiringan $(\boldsymbol{\beta})$ \\
\hline 1 & $0+75$ & $22^{\circ}$ \\
2 & $0+175$ & $21^{\circ}$ \\
3 & $0+275$ & $25^{\circ}$
\end{tabular}

Sumber: Pengamatan lapangan, 2018

Vegetasi yang tumbuh di lereng jalan sebelah timur beraneka ragam, baik yang tumbuh secara alami maupun yang ditanam masyarakat. Vegetasi terdiri dari pohon jati, pohon bambu, pohon pisang dan lain-lain. Pemanfaatan lereng jalan untuk lahan pertanian tidak memperhatikan manfaat tanaman sebagai perkuatan lereng.

\section{Pembahasan}

\section{Karakteristik tanah dasar ruas jalan Banjarparakan-Menganti}

Peta geologi lembar Banyumas dan Purwokerto menunjukkan bahwa tanah dasar di bawah timbunan ruas jalan lokasi penelitian merupakan tanah endapan. Tanah endapan yang terbentuk berada di area sungai disebut fluvial (Hardiyatmo, 2012). Endapan yang terjadi umumnya tidak padat dan mempunyai ukuran butiran yang relatif seragam. Tanah ini tidak menunjukkan perbedaan lapisan kearah horisontal. Disebabkan variasi sifat-sifat komposisi dan teknisnya, endapan fluvial sangat mudah sekali longsor bila tidak dalam kondisi tertahan.

Berdasarkan kadar air, tanah dapat berbentuk cair, plastis, semi padat, atau padat. Kedudukan fisik tanah berbutir halus pada kadar air tertentu disebut konsistensi (Hardiyatmo, 2002). Batas-batas konsistensi atau batas-batas Atterberg adalah batas cair (liquid limit), batas plastis (plastic limit), dan batas susut (shrinkage limit). Sifat keplastisan tanah ditunjukkan oleh indeks plastisitas (PI), yaitu selisih batas cair dan batas plastis.

Jika tanah mempunyai PI tinggi, maka tanah mengandung banyak butiran lempung. Sifat, macam tanah, dan kohesi diberikan oleh Atterberg pada Tabel 3.

Tabel 3 Nilai indeks plastisitas dan macam tanah

\begin{tabular}{clll}
\hline PI & \multicolumn{1}{c}{ Sifat } & \multicolumn{1}{c}{ Macam tanah } & \multicolumn{1}{c}{ Kohesi } \\
\hline 0 & Non plastis & Pasir & Non kohesif \\
$<7$ & Plastisitas rendah & Lanau & Kohesif sebagian \\
$6-17$ & Plastisitas sedang & Lempung berlanau & Kohesif \\
$>17$ & Plastisitas tinggi & Lempung & Kohesif \\
\hline
\end{tabular}

Sumber : Hardiyatmo, 2002

Hubungan kadar air di lapangan terhadap LL dan PL memperlihatkan jumlah pengurangan kadar air yang berakibat tanah kehilangan sifat-sifat plastis, sehingga tanah menjadi basah sama sekali atau cair, ataupun tanah menjadi kering atau tidak plastis lagi. Umumnya, tanah berbutir halus di lapangan dengan 
kadar air mendekati nilai LL-nya akan lebih lunak daripada tanah dengan kadar air yang mendekati PL-nya. Pada umumnya, kadar air lempung, pada kondisi alam, terletak dalam interval plastis (Hardiyatmo, 2012).

Tanah dasar (subbase) ruas jalan Banjarparakan-Menganti mempunyai nilai PI $=11,4 \%$. Dengan demikian tanah dasar (subbase) ruas jalan ini termasuk tanah lempung berlanau, kohesif dan mempunyai sifat plastisitas sedang. Tanah dengan plastisitas sedang menandakan karakteristik tanah yang kurang baik, karena sering menimbulkan hal-hal tidak diinginkan, seperti penurunan yang berlebihan, gerakan dinding penahan tanah, keruntuhan lereng, dan lain-lain.

Tanah dasar (subbase) ruas jalan Banjarparakan-Menganti dengan nilai LL $=69,5 \%$, menurut diagram Casagrande dikategorikan sebagai tanah MH (lanau plastisitas tinggi) atau $\mathrm{OH}$ (lanau organik plastisitas tinggi).

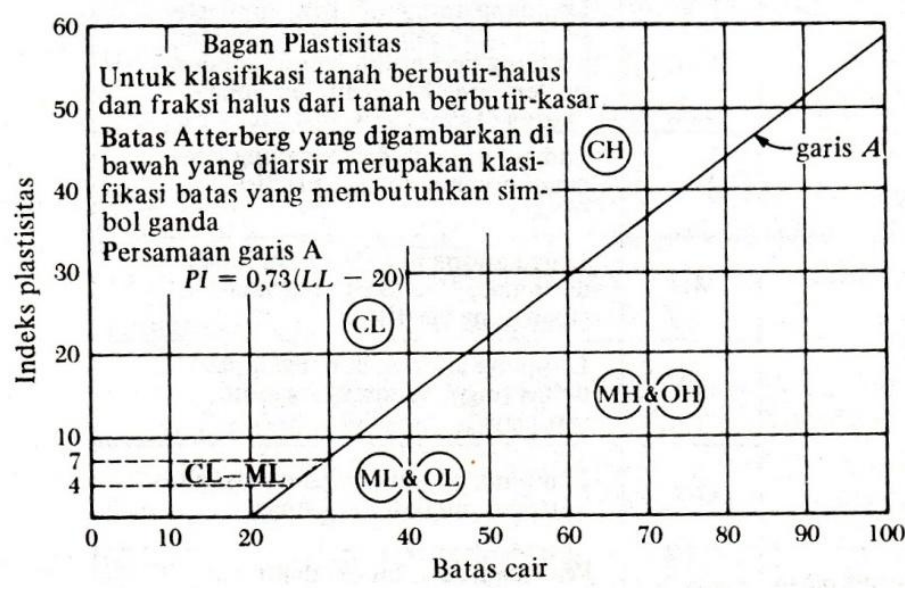

Gambar 3 Diagram plastisitas Casagrande

\section{Stabilitas lereng ruas jalan Banjarparakan-Menganti}

Analisis stabilitas lereng di ruas jalan Banjarparakan-Menganti dilakukan dengan program Geostudio Slope/W. Analisis dilakukan untuk menentukan faktor aman atau angka aman (safety factor) dari bidang longsor potensial. Analisis stabilitas lereng didasarkan pada konsep keseimbangan batas plastis (limit plastic equilibrium).

Analisis stabilitas lereng jalan dilakukan terhadap tiga titik stasiun. Ketinggian lereng dihitung dari permukaan jalan sampai kaki lereng. Kemiringan lereng bervariasi untuk setiap stasiun pengamatan (Tabel 2). Parameter sudut geser dalam, berat volume, kohesi, dan kadar air tanah untuk ketiga stasiun dianggap sama. Analisis dilakukan dengan menganggap muka air tanah sangat dalam, sehingga tekanan pori diabaikan.

Hasil analisi stabilitas lereng ditunjukkan dalam Gambar 4 - 6. 


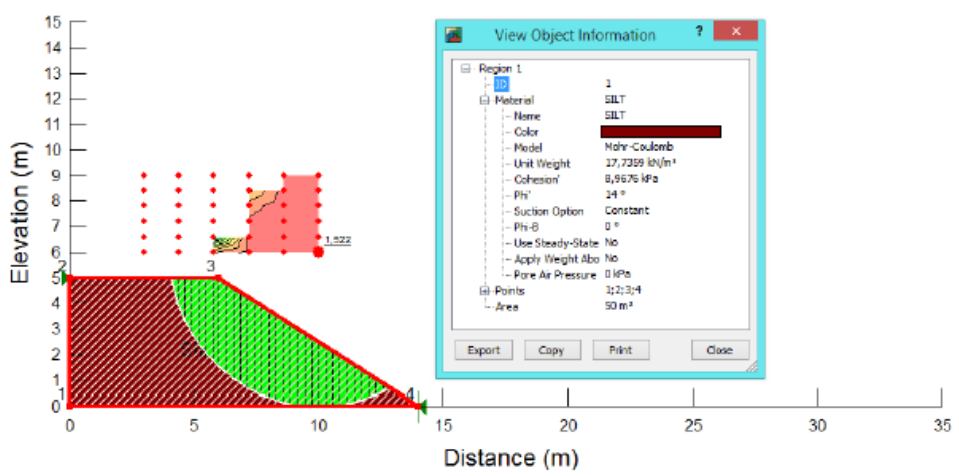

Gambar 4 Parameter tanah dan hasil analisis stabilitas lereng Stasiun 0+75

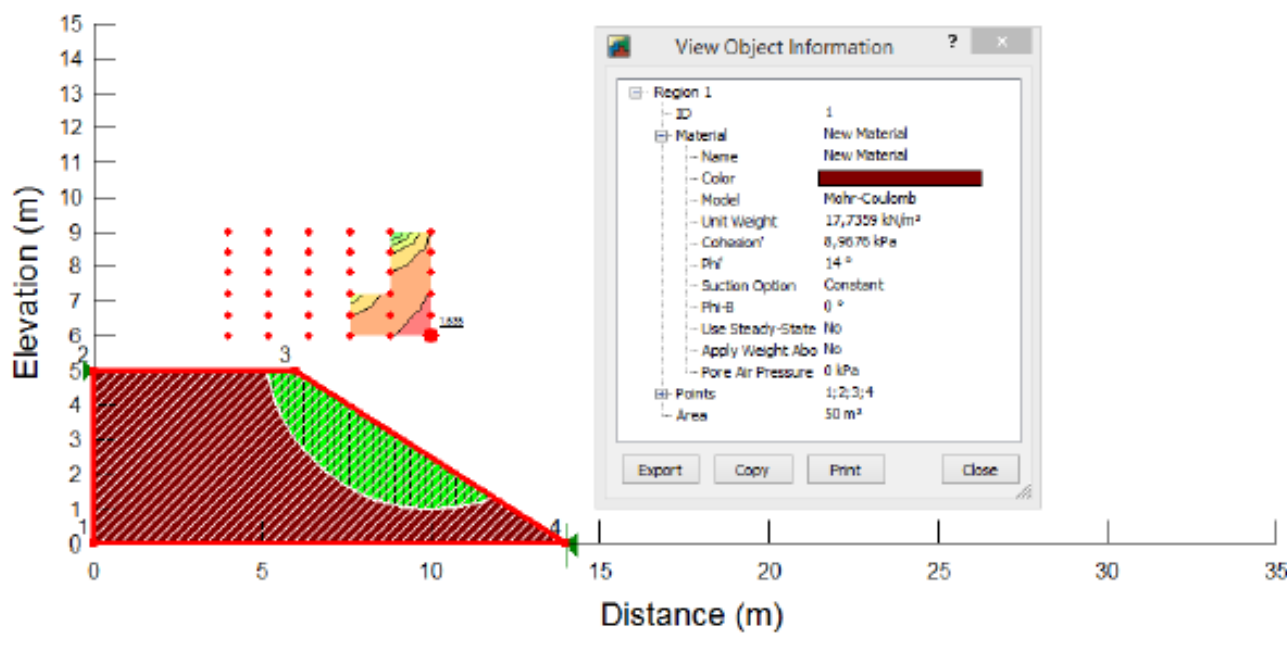

Gambar 5 Parameter tanah dan hasil analisis stabilitas lereng Stasiun 0+175

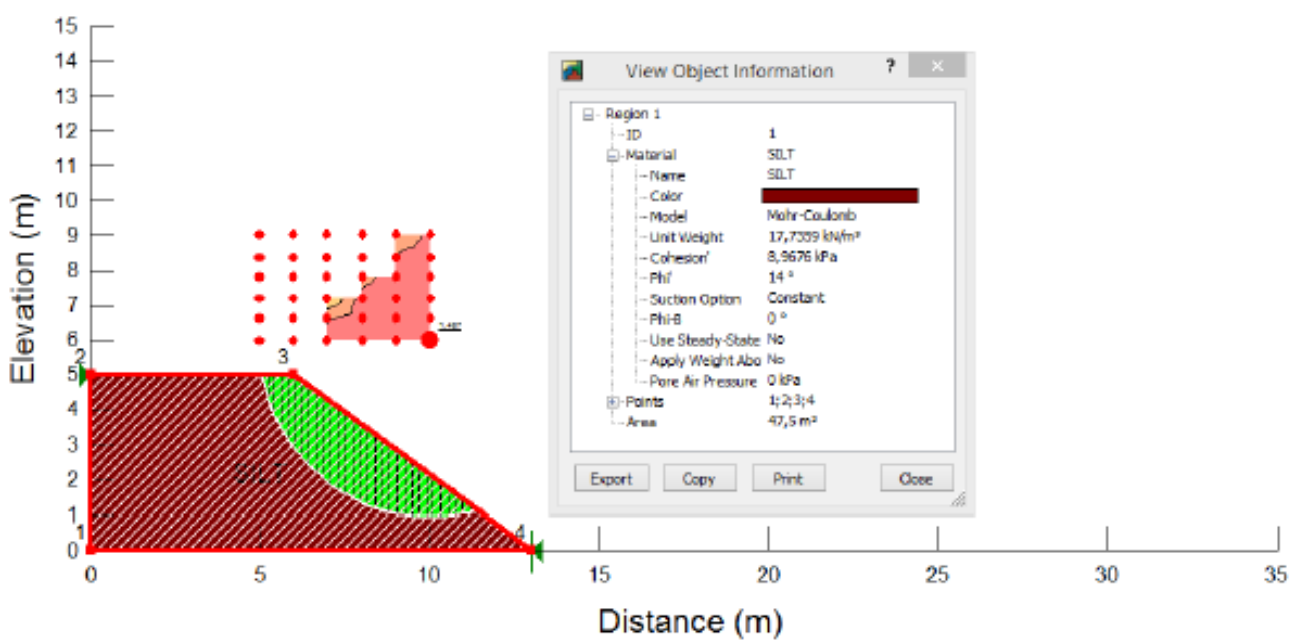


Gambar 6 Parameter tanah dan hasil analisis stabilitas lereng Stasiun 0+275

Hasil analisis stabilitas lereng di Stasiun 0+75, 0+175, dan 0+275 menghasilkan angka aman seperti yang diperlihatkan dalam Tabel 4.

Tabel 4 Angka aman lereng ruas jalan Banjarparakan-Menganti

\begin{tabular}{ccc}
\hline Stasiun & Angka aman & Keterangan \\
\hline $0+75$ & 1,52 & Lereng stabil \\
$0+175$ & 1,63 & Lereng stabil \\
$0+275$ & 1,48 & Lereng stabil \\
\hline
\end{tabular}

Sumber: Hasil analisis, 2019

Angka aman yang didapat belum menggambarkan kondisi lereng yang ideal, karena dalam analisis ini parameter tekanan air pori, beban kendaraan pada jalan, dan tambahan beban pada lereng belum dimasukkan.

\section{Penyebab longsor lereng dan ambles ruas jalan Banjarparakan-Menganti}

Penyebab longsor lereng dan ambles dapat dibagi menjadi dua, penyebab alami dan sebab-sebab yang terkait dengan aktifitas manusia. Penyebab alami misalnya pelapukan batuan, hujan lebat atau hujan tidak begitu lebat tapi berkepanjangan, adanya lapisan tanah lunak dan lain-lain. Penyebab terkait aktifitas manusia misalnya penggalian di kaki lereng, penambahan beban pada lereng dan muka jalan, tambahan beban oleh air yang masuk pori-pori tanah maupun yang menggenang di permukaan tanah dan beban dinamis oleh tumbuh-tumbuhan yang tertiup angina (Hardiyatmo, 2012).

Penanganan yang pernah dilakukan oleh Dinas Sumber Daya Air dan Bina Marga Kabupaten Banyumas pada Tahun 2014 adalah dengan perkuatan pondasi tiang sampai kedalaman 12 meter. Penanganan ini belum mampu menyelesaikan persoalan karena longsor lereng dan ambles pada ruas jalan Banjarparakan-Menganti masih terjadi.

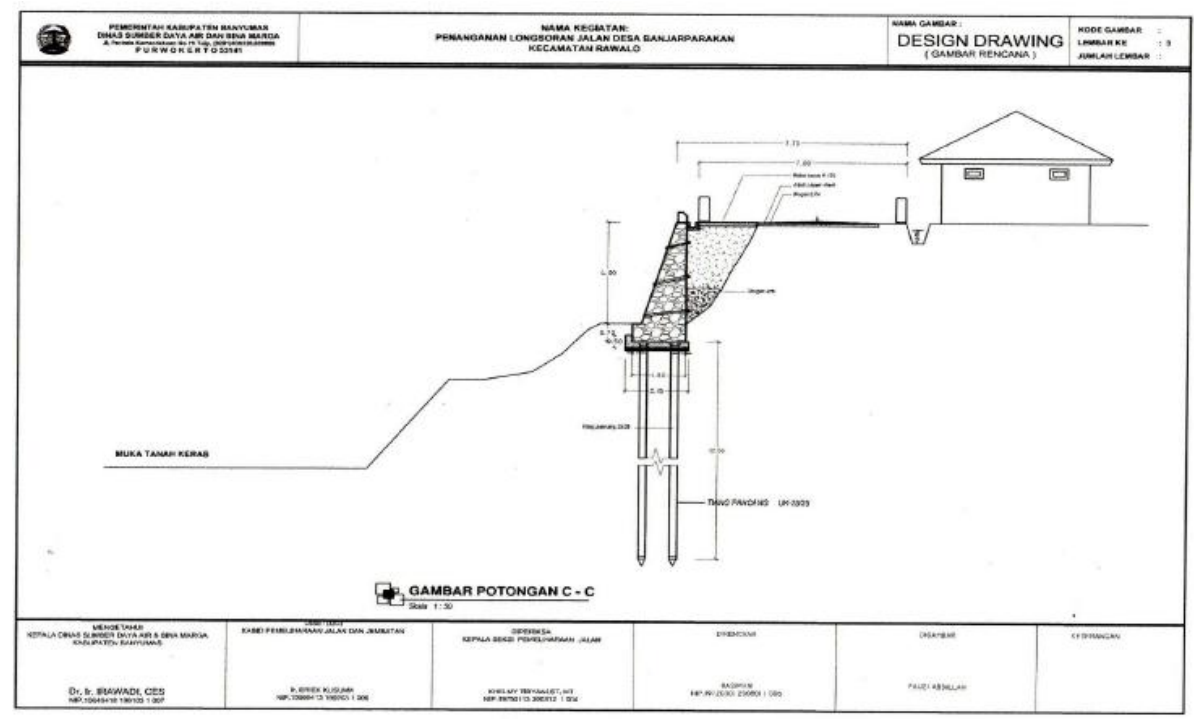


Gambar 7 Pemasangan dinding penahan tanah dan pondasi tiang pancang (Sumber: Dinas SDABM Kabupaten Banyumas, 2014)

Berdasarkan data jenis tanah dasar dibawah tanah timbunan jalan yang berupa tanah endapan yang cukup tebal, diperkirakan pemancangan pondasi tiang belum mencapai tanah keras. Kondisi ini justru menimbulkan penambahan beban pada lereng. Kondisi lain yang diperkirakan sangat berpengaruh terhadap stabilitas tanah dasar dan lereng adalah beban oleh air yang masuk ke pori-pori. Air yang berinfiltrasi ke dalam tanah, kecuali mengurangi kuat geser tanah juga menambah berat sendiri tanah pembentuk lereng. Kombinasi keduanya sering menjadi sebab terjadinya longsor lereng (Hardiyatmo, 2012).

Karakteristik tanah subbase yang mempunyai indeks plastisitas sedang menandakan karakteristik tanah yang kurang baik, karena sering menimbulkan hal-hal tidak diinginkan, seperti penurunan yang berlebihan, gerakan dinding penahan tanah, keruntuhan lereng. Hal seperti ini tampak pada peristiwa amblesnya ruas jalan Banjarparakan-Menganti.

Beberapa penyebab longsor lereng dan ambles ruas jalan Banjarparakan-Menganti.yang dapat disimpulkan sebagi berikut:

1. Pemancangan tiang pancang diperkirakan tidak mencapai tanah keras.

2. Dinding penahan tanah menambah beban pada lereng yang menyebabkan tekanan tanah menjadi naik.

3. Pengaruh tekanan air pori yang diperkirakan cukup besar, terutama bila terjadi hujan. Hal ini bias terjadi karena jenis tanah dasar dan tanah timbunan berupa tanah endapan yang umumnya tidak padat dan mempunyai ukuran butiran yang relatif seragam.

\section{KESIMPULAN}

Berdasarkan hasil identifikasi lapangan, hasil analisis dan pembahasan yang telah dilakukan, dapat ditarik beberapa kesimpulan sebagai temuan penelitian sebagai berikut:

1. Tanah dasar dibawah timbunan ruas jalan Banjarparakan-Menganti berupa endapan fluvial yang sangat mudah sekali longsor bila tidak dalam kondisi tertahan. Tanah dasar (subbase) ruas jalan Banjarparakan-Menganti mempunyai nilai PI = 11,4\%, termasuk tanah lempung berlanau, kohesif dan mempunyai sifat plastisitas sedang. Tanah jenis ini mempunyai karakteristik tanah yang kurang baik, karena sering menimbulkan penurunan yang berlebihan, gerakan dinding penahan tanah, keruntuhan lereng, dan lain-lain.

2. Stabilitas lereng ruas jalan Banjarparakan-Menganti eksisting pada tiga stasiun pengamatan termasuk kategori stabil.

4. Penyebab longsor lereng dan amblesnya ruas jalan Banjarparakan-Menganti diperkirakan karena pemancangan tiang pancang tidak mencapai tanah keras, tambahan beban dinding penahan tanah pada lereng, dan pengaruh tekanan air pori yang diperkirakan cukup besar, terutama bila terjadi hujan. 
Saran

Mengingat terbatasnya data yang ada dan belum adanya solusi akhir dalam penanganan ruas jalan Banjarparakan-Menganti, maka disarankan beberapa hal sebagai berikut:

1. Perlu dilakukan penyelidikan tanah yang lebih detail dan sampai kedalaman dibawah muka tanah kaki lereng.

2. Perlu analisis stabilitas lereng dengan beban kendaraan dan tekanan air pori.

3. Perlu dikakukan analisis dan desain ulang perkuatan lereng jalan.

\section{DAFTAR PUSTAKA}

[1] Anonim. 2006. Peraturan Pemerintah Republik Indonesia Nomor 34 Tahun 2006 Tentang Jalan.

[2] Azizi, A., dan M.A. Salim. 2013. Analisis Kestabilan Lereng Kawasan Bencana Tanah Longsor di Desa Binangun Kecamatan Banyumas, Laporan Penelitian Hibah Program Studi, LPPM. UMP, Purwokerto.

[3] Direktorat Jenderal Penataan Ruang, 2007, Pedoman Penataan Ruang Kawasan Rawan Bencana Longsor, Departemen Pekerjaan Umum, Jakarta

[4] Hardiyatmo, H.C. 2012. Tanah Longsor dan Erosi Kejadian dan Penanganannya, Gadjah Mada Uinersity Press, Yogyakarta.

[5] Hardiyatmo, H.C. 2002. Mekanika Tanah I, Gadjah Mada University Press, Yogyakarta.

[6] Hardiyatmo, H.C. 2015. Pemeliharaan Jalan Raya, cetakan ketiga, Gadjah Mada University Press, Yogyakarta

[7] Hardiyatmo, H.C. 2012. Stabilisasi Tanah Untuk Perkerasan Jalan, cetakan pertama, Gadjah Mada University Press, Yogyakarta

[8] Radhakrishnan, G. dkk. 2014. Swelling Properties of Expansive Soils Treated with Chemicals and Flyash. American Journal of Engineering Research (AJER), Volume-03, Issue-04, pp-245-250.

[9] Rahardjo, H., et al. 2002. Studies of Rainfall-induced Slope Failure, Prosiding Seminar Nasional SLOPE 2002, Bandung

[10] Ramia, I.N. 2017. Analisis Dinding Penahan Untuk Perkuatan Kelongsoran Lereng di Jalan Bedugul Singaraja. Jurnal Matrix, Vol. 7 No.3, p-64-67

[11] Suryanto, B.E. 2017. Analisis Karakteristik Tanah Dasar Pada Segmen Jalan Amblas Jalan BanjarparakanMenganti Kecamatan Rawalo Kabupaten Banyumas. Skripsi. Program Studi Teknik Sipil Fakultas Teknik dan Sains Universitas Muhammadiyah Purwokerto.

[12] Suryolelono, K.B., 2003, Bencana Alam Tanah Longsor Perspektif Ilmu Geoteknik, Pidato Pengukuhan Jabatan Guru Besar Pada Fakultas Teknik Universitas Gadjah Mada, Yogyakarta.

[13] Wiqpyah, Q., dan Sri Mulyani R.W. 2006. Evaluasi Penanganan Kelongsoran Pada Ruas Jalan MajenangWanareja (Cilacap) dan Penanganannya Dengan Geotekstil. Jurnal Dinamika Teknik, Volume 6, Nomor 2, p77-84 